\title{
An Introduction to the Capital Market of a Leading Petrochemical Company in Croatia: Case Study
}

Marina Klačmer Čalopa, Goran Bubaš, Ksenija Vuković*

\section{Abstract:}

The Croatian company under state ownership that underwent the process of an introduction to the capital market was the leading regional petrochemical company, INA Oil Industry. The process of introduction to the capital market started in 2006 when the Croatian government announced that it will sell 15\% of INA shares to small investors, Croatian citizens with some pre - emptive rights and under special conditions. In the text, the authors describe the short-term and long-term performance of shares, factors that influence the perception of privatized companies and the phenomenon of underpricing of shareholder issues. Finally, the introduction to the capital market of INA shares is briefly presented as a case study. This paper reports the research results of a survey of the perception of INA company and of the introduction to the capital market of INA's shares by the potential small investors and the influence of those perceptions on stock purchase motivation.

Keywords:

JEL:

DOI: $10.2478 / \mathrm{v} 10033-008-0016-6$

\section{Introduction}

This paper analyzes a case of the introduction of stateowned shares to the capital market of Croatia and the results of a survey on the perceptions among potential small investors of the company that was privatized. In the second half of 2006, the government of Croatia announced that it would sell $15 \%$ of the shares of the leading regional petroleum company, INA Oil Industry (INA), to small investors, primarily to Croatian citizens with some pre-emptive rights and under special conditions. This process of introduction to the capital market of INA shares is briefly presented as a case study. In addition, to capture at least some of the sentiment of potential investors, the authors performed a survey on the perceptions held by potential small investors of various attributes of INA,andalso ofvarious otherelements associated with the privatization of INA that could have influenced their decisions. It must be noted that the privatization of INA began in 2002 when another regional petroleum company, MOL (based in Hungary), purchased $25 \%$ plus one share of INA.The introduction process of INA shares occurred in 2006 and in this paper will be referred to as the introduction to the capital market of INA shares.

Going public is always a large structural process for any
company.It is connected with share issue privatization (Wang, $\mathrm{Xu}$, and Zhu 2004) and government decisions to choose a public privatization method, especially in the case of formerly state-owned companies. The main reason for privatization is to create market-oriented companies competent to conduct business in an internationally competitive environment. The largest process of privatization started in the 90 s when most transitional countries started to change their economic,

\footnotetext{
*Čalopa:

Faculty of Organization and Informatics Varaždin

Pavlinska 2,Varaždin, Croatia

e-mail:marina.klacmer@foi.hr

*Bubaš:

Faculty of Organization and Informatics Varaždin Pavlinska 2, Varaždin, Croatia

*Vuković:

Faculty of Organization and Informatics Varaždin Pavlinska 2, Varaždin, Croatia
} 
organizational and marketorientation.Thecorporations often chose the "go public" model after they became privatized. Through the process of introduction to the capital market, small investors for the first time had the opportunity to buy company common stocks and generate an opportunity for significant liquidity.The decision to go public forgovernmentowned enterprises may have the following positive effects (Brau and Fawcett 2006; Gupta 2005; Megginson, Nash, and Van Randenborgh 1994; Pagano, Panetta, and Zingales 1998): (i) improved financial liquidity; (ii) increased share value; (iii) increased profitability;(iv) greater productivity and operating efficiency; $(v)$ increased capital investment and investment in R\&D; (vi) increased real sales; (vii) an increased workforce; (viii) the creation of public shares that can be used in future acquisitions, and (ix) not having to repay the raised capital, as is the case with debt securities. These potential benefits create interest in both stable and developing economies.

According to Braw and Fawcett (2006), the motives for going public may be to lower the cost of capital, to improve the firm's public relations and reputation, to facilitate takeover, or to enable insiders to sell their stock. In their survey, these authors revealed that the timing of going public was most influenced by the overall stock-market conditions, industry conditions, and the need for capital growth. Jain and Kini (1999) claim that going public is a stage in the evolution of a public company, and that for private firms this process may reflect the motivation of the directors of the firm to finance investment and expansion, rebalance accounts after periods of growth, subsequently sell a firm, and/or the assessment that growth potential is decreasing and that it is opportune for the directors to sell their holding. It must be noted that in the post stage of this type of privatization, the company may survive, fail, or be acquired, all of which is determined by a number of rather complex variables.

Various countries have different backgrounds, motives and experiences with regard to their state-owned firms going public. The history of going public shows some important differences between the markets in the USA and Europe (Ritter 2003). European markets have only recently started their development, especially in Central and Eastern Europe. At the beginning of their development, they used different methods and mechanisms for privatizing their state-owned companies. One interesting difference between the markets in the USA and Europe is that European companies (especially those from continental Europe) that are privatized by going public are usually much older than those in the USA. In the UK, large firms with issues greater than $£ 5$ million are more likely to choose a public offering instead of listings on the capital market (Goergen, Khurshed, and Mudambi 2006), with state-owned companies yielding relatively large returns to investors (Stevenson 2006), at least at the short-run. In Germany, the common result of going public is companies being controlled by old shareholders or new shareholder groups, while in the UK the post ownership is more widely dispersed (Goergen and Renneboog 2007). The Italian stock market has specific characteristics that are also shared with some other countries in continental Europe, since older and larger companies are more likely to be motivated towards going public (typical are on average up to 8 times larger than in the USA), and the likelihood of an public offering is also greater for industrial sectors with a high market-tobook ratio and for those firms that expect to rebalance their accounts after periods of growth (Pagano, Panetta, and Zingales 1998).

Research also shows that companies reduce their cost of bank credit after going public. One of the reasons for this effect could be connected with better public information and transparency, which are requirements for all listed companies. In Canada there was a tradition of state-owned and government supported public enterprises, many of which were gradually sold to private investors (Taylor and Warrack 1998). One of the reasons why Canada is rather government oriented is because of its relatively small financial and economic markets. Sometimes, under monopolistic circumstances, a country can be more competitive on the international market. In the UK, large and multinational companies are more likely to choose going public, especially when the market is "hot", while for small issues the more frequent choice is placing, which often avoids the costs and risks of the public issuing of shares (Goergen, Khurshed, and Mudambi 2006). Going public in China was a major form of privatization for large and better-performing state-owned and state-controlled enterprises. Among other things, this was motivated by the potentially positive effects on company profitability and on the reduction of debt finance (Wang, Xu, and Zhu 2004). Privatization plays a very important role in the countries of the European Union (Schneider 2003) as an element of structural reform. Still, the largest numbers of state-owned companies that underwent privatization have been in Japan. After Japan, the privatization of state-owned companies through going public was relatively frequent in the 90s in European countries such as Great Britain, Italy, France and Germany. Also, the 90s were most important for transitional countries, as for most the privatization processes started at that time. All transition countries were at first non-market oriented, but they also had a large state sector that was considering various models of privatization. In the period from 1990 to 2000 in transitional countries, the largest number of state-owned companies that underwent the privatization were in Hungary and the Czech Republic.

\section{The Short-term and Long-term Performance of Stocks}

After an extensive review of literature, Deventer and Malatesta (1997) conclude that there is an abundance of evidence from capital markets in numerous countries of the underpricing of shares of state-owned companies. Hill 
(2006) analyzed several theories that attempted to explain the underpricing of shares and presented some of the reasons for underpricing: the possibility to limit the size of stakes in the company; the plan to achieve more widespread share ownership; the intention of the directors to maintain control of the company; the potential to increase the scale of purchasing; the intention to encourage oversubscription; an effort to persuade share owners to keep their shares; and the possibility of excessive demand among small investors. Other reasons may include the following: uncertainty about the value of the company; the existence of hot and cold time periods; privatization as a reason for the going public; the specific industry group of the company undergoing on capital market (Gerbich, Levis, and Venmore-Rowland 1995); the immaturity of the capital market; privatization in regulated industries; the intention of government officials to increase domestic political support for privatization or to achieve other benefits (Dewenter and Malatesta 1997); avoidance of the risk that the after-market price will fall below the offer price (Tiniç 1988); analyst over-optimism (Rajan and Servaes 1997); the over-optimism of gray market investors and the volume of gray market trading (Cornelli, Goldreich, and Ljungqvist 2006); the creation of a signal to investors that the firm is good for investment (Kim, Krinsky, and Lee 1993); the aspiration of underwriters to acquire analyst research coverage with stock purchase recommendations; and building stock price momentum for the sales of insiders' stocks after the expiration of the lockup period (Cliff and Denis 2004).

Underpricing and good stock performance on the first day of trade may be a means for generating publicity among investors that raises stock value on secondary markets (Chemmanur 1993). For instance, the state-owned company in Croatia (the petroleum company INA) to be privatized through an introduction to the capital market saw its stock value increase by almost $68 \%$ in the first hour of trade. This is one of the outcomes of a going public model of privatization that signals stock value to potential investors.

There are empirical findings that the initial returns from going public are positively related to limited investor accessibility to the shares in the primary market and to the level of risk associated with the absence of a substitute for a new issue in the secondary market, as well as negatively related to offering size (Mauer and Senbet 1992). It must be noted that,in some cases, when a developing market reaches a critical mass of investors and listed firms, it can experience a "snowballing" effect, with new listings of firms and new investors entering the market. This can be stimulated by relatively limited governmental action (Subrahmanyam and Titman 1999). One of the interesting anomalies related to the performance of the stocks of companies that have gone public is the occurrence of abnormally large returns on the first day of trade as an indication of deliberate underpricing to subscribing investors (Gerbich, Levis, and
Venmore-Rowland 1995). A recent study reported that an average first day return in 38 countries was in the range of $+5 \%$ in Denmark to $+257 \%$ in China (Ritter 2003).

Despite numerous positive reasons for the privatization of state-owned companies and the frequent relatively large short-term returns for investors, research findings indicate that on average there is a long-term underperformance of the stocks of post public offering firms. For instance, Stehle, Ehrhard, and Przyborowsky (2000) found that in the German capital market public offering did not perform as well as a portfolio of stocks of other companies that had comparable market capitalization. Nevertheless, the degree of underperformance was considerably less than in the US market.

\section{Factors that Influence the Perception of Privatized Companies and Future Stock Performance}

Government ownership and the decisions of the management of a state-owned company regarding privatization and share issues send diverse signals to potential investors. A one-time sale of all governmentowned shares may signal the intention to transfer control to private investors, or that the government is trying to dump a company that is considered a problem (Sun, Tong and Tong, 2002). On the other hand, selling a smaller proportion of shares may signal the government's confidence in the company, or that the government's intention to continue interventions in its operation. Other signals that may have a positive effect on the interest of potential investors and the perception of firm quality are the choice of a prestigious underwriter, a reputable accounting firm for analysis, the commitment of insiders to a long lockup, a history of strong earnings, and venture capital backing (Brau and Fawcett 2006). One more reason for underpricing may be to signal the "value" of the firm to uninformed investors, with the implication that the amount of future cash flows would be in proportion to the amount of shares retained in the portfolio of the issuer (Grinblatt and Hwang 1989).

Along with the pricing and distribution services, the underwriters also provide related marketing services for issuers that occur in the pre- and post-offer period (Logue et al.2002). These activities may also include diverse signals aimed at raising the interest of investors. A reputable and big underwriter will be more ready to support an overpriced public offering than a smaller one because the former underwriter is potentially more skilled and has a better working performance (Lewellen 2006). The reputation and quality of the underwriter positively influence the efficiency of the sale of stocks, the perception of the investors of the quality of an issuer, and the confidence of investors that the shares are being sold at a fair price. In turn, this can support the effective positioning of the stock price (see: Logue et al. 2002). 
Auditor credibility is another way to signal favourable future earnings, and entrepreneurs may find it reasonable to select credible auditors for the going public (Menon and Williams 1991).Institutional investors are the most informed investors that have a central position in privatization processes with the potential to influence the price of shares (Jenkinson and Jones, 2007). The announcement of the interest of institutional investors in buying shares is one more way to signal potential share value. Finally, the amount of analyst coverage for a firm around the date of the public issue is associated with the superior performance of stocks in the mid-term period after the public offering (Das, Guo, and Zhang 2006). This should have a positive impact on first day returns.

Media provide diverse information that influences the impressions of firms that are going public and their stock turnover on the first day of trade, but the media can also reflect the public evaluation of a company and serve as a propagator of firm legitimacy (Pollock and Rindova 2003). The investors' valuation of the firms' management team may be one of the most important factors that influence investment decisions, while the public perception of management prestige can signal organizational legitimacy (Lester et al. 2006), with a potential positive effect on investor valuations of firms. Furthermore, the credibility of management and its reputation for extracting only low levels of private benefits may also have a positive effect on the valuation of the firm by minority shareholders (see: Gomes 2000).Venture capitalists are often members of the board of directors, and venture-backed firms may perform better after going public because they can participate in the selection of the firms' management and may continue to provide access to capital for the firm (Brav and Gompers 1997). Finally, firms that have a CEO who is the founder of the firm, those with more stable boards of directors, and with an outside blockholder present are more likely to survive (without takeover) during the first five years after going public (Howton, 2006).

\section{The Case of the Privatization of the INA Petroleum Company}

Privatization in the form of the deliberate sale of stateowned companies occurs in countries around the world, with growing evidence that such forms of privatization are associated with both promises and perils (for an overview of privatization worldwide, see Megginson and Netter, 2001). The privatization model in Croatia was depended on the company, and was also part of a social programme resting on a coupon privatization process. Until this time, Croatia did not have a defined model of privatization, and decisions regarding the form of privatization depended on the company's activity, its organizational structure, and its importance to the Croatian economy. The legal basis of Croatian privatization was the Transformation
Act of 1991 and the Privatization Act of 1993, amended in 1996. It must be noted that in Croatia large infrastructure and utility industries, such as those in the fields of oil and telecommunications, are privatized on the basis of special laws. Most of the early privatization activities in Croatia have generally been perceived as socially unacceptable and economically inefficient (see: Druzic and Gel, 2006).

Until recently, the process of an introduction to the capital markets in Croatia was not a standard mode of raising capital for financing company projects, i.e. for further company development.The reasons for this are privatization processes that from the beginning of the 1990s were conducted by using the model of employee shareholding or by selling the company to a strategic partner.

In July 2003, the Croatian government decided to offer $25 \%$ plus one INA shares to INA's strategic partner Hungarian Oil and Gas (MOL). That process marked the first phase of INA's privatization, when 2,500,001 shares of a nominal value of EUR 121.62 (HRK 900) per share were sold to the strategic partner MOL. Having acquired $25 \%$ plus one shares, MOL gained the right to participate in strategic decision-making in INA. Through this strategic partnership, INA became part of a regional partnership in the oil and gas industry.

The introduction to the capital market of $15 \%$ of shares was announced by the Croatian government in October 2006. There was also a potential option to sell an additional $2 \%$ of INA shares. This model of privatization marked the second, more significant privatization stage of the biggest oil company in Croatia. International institutional investors based outside Croatia were also able to buy regular INA shares. In parallel to the process of introduction to the capital market, there was the gathering of necessary documentation for the listing of regular INA shares on the First Quotation of the Zagreb Stock Exchange. The preparation for attracting institutional investors was also made by listing regular INA shares on the London Stock Exchange. The listing of shares on the First Quotation of the Zagreb Stock Exchange was supposed to encourage the development of the Croatian capital market and to encourage a greater number of Croatian citizens to actively participate in the capital market.

\section{INA Introduction to the Capital Market and the Perceptions of Potential Small Investors}

To investigate the perceptions of potential small investors in the INA company, and of the introduction to the capital market of INA shares, a survey was performed regarding the perceptions of different attributes of INA and various aspects of the introduction to the capital market of INA shares. The data collected from this survey were analyzed to determine the elements that influence motivation to purchase INA shares in the process of its introduction to the capital market. 


\subsection{Problem and Hypotheses}

The main aim of this study was to investigate if the perceptions of the attributes of the INA company and of the aspects of the introduction to the capital market of INA shares influence the motivation of potential small investors to buy the shares of INA in the process of its introduction.

The first hypothesis of this study is connected to the main aim of this paper, and is defined as follows:

$\mathrm{H} 1$ : The perceptions among potential small investors with regard to the various attributes of the INA company and different aspects of the introduction of INA shares to the capital market are related to the investors' motivation to purchase INA shares in the process of introduction.

Since diverse types of attributes of the INA company and aspects of the introduction to the capital market of INA shares were investigated in the survey, one important research question was related to the possible categorization of those attributes and aspects. Therefore, a second hypothesis was defined:

$\mathrm{H} 2$ :The perceptions of the attributes of the INA company and different aspects of the introduction of INA shares to the capital market can be categorized by the basic factors influencing the motivation of potential small investors to purchase INA shares.

\subsection{Method}

A survey was designed with 95 items related to the perceptions of different attributes of INA and various aspects of its introduction to the capital market, and also to variables that were an indication of the intent to purchase INA shares, and demographic data. The convenience sample in the survey consisted of 171 subjects aged $18-72$ years, of whom $59 \%$ were male, and $89 \%$ were employed or retired. The data collection was performed by students who were asked to administer the survey to adults who had considered purchasing INA shares. The survey was performed before the shares were listed on the Croatian capital market.

\subsection{Results of data analysis}

A correlation analysis was performed between the variables of the survey that represented the perceptions of different attributes of the INA company and aspects of the introduction of INA shares, and the motivation to purchase the shares of INA in the introduction process. The motivation variable was represented with the survey item "If I had available funds and an opportunity to do so, I would purchase as many shares of the INA company under the discount price as I could. "All of the items in the survey that were used in this correlation analysis were statements (see Table 1) to which the subjects responded on a Likert-type scale ranging from
" 1 - totally untrue of me", to " 5 - totally true of me". As can be concluded from the data presented in Table 1, as many as 41 variables were found to have a statistically significant positive correlation at the level of $p<0.01$ with the motivation to purchase INA shares. The highest correlation $(r=0.51)$ was found between motivation to purchase INA shares and the assessment that the number of people who had signed up to purchase INA shares was an indication of the profitability of investment in that company. Also, a high influence on motivation was the expectation of a rise in the value of INA shares in the following 2-3 years $(r=0.50$; this opinion was shown in the media) and in the perception of the sincerity of the government of Croatia and the transparency of the introduction process $(r=0.40)$. The motivation to purchase INA shares was also influenced by the perception of the good relationship of INA with its customers $(r=0.39)$ and by the earlier steep rise in the value of shares of Pliva $(r=0.38)$, the leading pharmaceutical corporation in the region. Other diverse attributes of INA and aspects of introduction to the capital market also positively influenced the motivation to purchase shares. In addition, several attributes of INA and aspects of the introduction process were found to have a statistically significant $(p<0.01)$ negative correlation with the motivation to purchase INA share.

To categorize the attributes of INA and the aspects of the introduction process that had a statistically significant positive or negative correlation with the motivation to purchase shares of INA, a factor analysis of 66 related variables was performed. The results of this analysis are presented in Table 2 (only the five variables with highest loading on each the uncovered factors are displayed). Three factors shown in Table 2 explain 30\% of the variance and represent the most interpretative factor solution for a given set of variables and data collected from subjects $(\mathrm{N}=171)$. It must be noted that 21 factors were found in the initial unrotated factor solution with eigenvalues greater than 1.0, and that the Scree test indicated that 3-4 factors should be used for further analysis with varimax rotation. The variables with the predominant projection of the first factor (F1) in Table 2 appear to be related to the perceptions of the positive corporate image of the INA company. The second factor (F2) in Table 2 can be interpreted as the perceptions of the political aspects of the introduction process of INA and the privatization environment in Croatia. Finally, the third factor (F3) is related to shareholder pessimism and the elements of negative corporate image of the INA company. It must be noted that because of space limitations, only the first five variables with the highest loading on respective factors are displayed in Table 2. 


\begin{tabular}{|c|c|}
\hline $\begin{array}{c}\text { Correlation } \\
\text { withmotivation }\end{array}$ & $\begin{array}{l}\text { PERCEPTIONS OF THE ATTRIBUTES OF THE INA COMPANY AND OF THE ASPECTS OF THE INA INTRODUCTION } \\
\text { PROCESS }\end{array}$ \\
\hline .51 & $\begin{array}{l}\text { It is my assessment that the number of people who have signed up for the purchase of the shares of INA is an indication } \\
\text { that investment in this company will be profitable. }\end{array}$ \\
\hline .50 & I expect that the price of shares of the INA company will considerably increase in the next 2-3 years. \\
\hline .40 & $\begin{array}{l}\text { I have confidence that the activity of selling INA shares conducted by the government of Croatia is sincerely motivated } \\
\text { and transparent. }\end{array}$ \\
\hline .39 & I believe that the relationship of the INA company and its customers is especially good. \\
\hline .38 & $\begin{array}{l}\text { The sudden increase in the value of shares of the Pliva }{ }^{\dagger} \text { corporation before takeover has had a positive influence on my } \\
\text { view that people who buy shares of the INA company can make a good profit. }\end{array}$ \\
\hline .38 & $\begin{array}{l}\text { I assume that the introduction to the capital market of INA shares is politically motivated, with the goal that } \\
\text { people who become shareholders in this company are in the end satisfied with their purchase of INA shares. }\end{array}$ \\
\hline .37 & I believe that, regarding its geographical position in the region, INA has a great strategic advantage. \\
\hline .36 & In my opinion, the products and services of INA are above average on the domestic market. \\
\hline .35 & $\begin{array}{l}\text { I consider as very attractive the promise that the owners of the shares of INA that are purchased during the } \\
\text { introduction process, who do not sell their stock in the first } 12 \text { months after purchase, will receive one more extra } \\
\text { complimentary share. }\end{array}$ \\
\hline .35 & I assume that INA will employ more personnel than they will dismiss. \\
\hline .34 & $\begin{array}{l}\text { I believe that especially negative events should not be expected in the business environment of INA in the next } \\
\text { several years. }\end{array}$ \\
\hline .32 & I consider INA to be a well-organized firm. \\
\hline .31 & $\begin{array}{l}\text { I notice that INA, over a longer time period, and not only in the last month or two, is more and more admired in the eyes } \\
\text { of its customers/clients. }\end{array}$ \\
\hline .30 & I think that I can always rely on the quality of INA products. \\
\hline .29 & In my opinion, the management of INA is known for its good decisions. \\
\hline .29 & I think that the production facilities of INA are very modern. \\
\hline .28 & $\begin{array}{l}\text { It is my opinion that the generally low interest rates for bank savings have a considerable influence on the } \\
\text { assessment of profitability of investment in a company like INA. }\end{array}$ \\
\hline .28 & I think that INA stands out by its size in relation to other similar companies in the region. \\
\hline .27 & I do not see any reason for a decrease in the production of INA in the next several years. \\
\hline .26 & I think that the business results achieved by INA in the last several years have been very good. \\
\hline .25 & $\begin{array}{l}\text { There is greater risk of losing the value of cash deposited in a bank than there is of losing by investing in a } \\
\text { company like INA. }\end{array}$ \\
\hline .25 & $\begin{array}{l}\text { I think that INA is good at combining exploration directed at discovering new oil and gas deposits with the } \\
\text { activities of production, distribution and sales. }\end{array}$ \\
\hline .24 & I see the biggest advantage of INA in its well-developed retailing network. \\
\hline .23 & I assume that the management of INA will be in the hands of conscientious and competent people. \\
\hline .23 & $\begin{array}{l}\text { I suppose that the eventual obsoleteness of some production facilities will not have a serious negative impact on } \\
\text { the profitability of INA. }\end{array}$ \\
\hline .22 & INA has a great advantage because of the numerous qualified experts that it employs. \\
\hline .22 & The influence of the state on the INA company is predominantly stimulating and oriented toward its development. \\
\hline .22 & I consider the product prices of INA to be very competitive. \\
\hline .22 & $\begin{array}{l}\text { According to my insight into the content of the electronic (TV, radio, Internet) and printed media (daily and weekly } \\
\text { newspapers and magazines), the marketing of INA products is very good. }\end{array}$ \\
\hline .21 & $\begin{array}{l}\text { I do not expect that in the near future (several years) there will be any problem for INA regarding raw material and } \\
\text { crude oil for its products. }\end{array}$ \\
\hline-.21 & $\begin{array}{l}\text { I have considered that restrictions on carbon dioxide emissions on account of global warming can have a negative } \\
\text { impact on the business activities of energy companies like INA. }\end{array}$ \\
\hline-.21 & $\begin{array}{l}\text { I am aware that the inability of INA to modernize its refineries in Sisak and Rijeka }{ }^{\text {t+ }} \text { on time and comply with the } \\
\text { European norms for fuel quality may have a negative impact on its business success. }\end{array}$ \\
\hline-.21 & In my opinion, INA has numerous internal weaknesses that have a negative impact on its business. \\
\hline-.21 & $\begin{array}{l}\text { I believe that some other energy/petrochemical companies in the wider region are better placed as leaders on the } \\
\text { market than is the case with INA. }\end{array}$ \\
\hline-.23 & It seems to me that the great competitors of INA are better organized and more efficient. \\
\hline-.24 & $\begin{array}{l}\text { lbelieve that the reputation of INA as the leading petrochemical company in the region has been impaired during the last } 2-3 \\
\text { years. }\end{array}$ \\
\hline-.25 & $\begin{array}{l}\text { Te is my assessment that Croatia is an unstable country in which the long-term stability of a company like INA is } \\
\text { questionable. }\end{array}$ \\
\hline-.26 & $\begin{array}{l}\text { I think that the events in the Middle East, and in other countries that produce crude oil (e.g. Russia, Venezuela, } \\
\text { Mexico) can have a negative impact on the profitability of INA. }\end{array}$ \\
\hline-.30 & $\begin{array}{l}\text { I think that behind the selling of shares of INA through an introduction process there are some motives that are } \\
\text { hidden from the general public. }\end{array}$ \\
\hline-.30 & $\begin{array}{l}\text { Tam aware that there is possibility that dividends paid for INA shares will be no greater than the interest rate for cash deposits in } \\
\text { a bank. }\end{array}$ \\
\hline
\end{tabular}

+ Pliva is a leading regional pharmaceutical company.

${ }^{++}$Sisak and Rijeka are the locations of two major refineries of INA.

Table 1. Attributes of the INA company and aspects of the introduction process of INA shares that are correlated with the motivation to purchase the shares $(\mathrm{N}=171 ; \mathrm{p}<0.01$ for all correlations) 
To test if the three factors presented in Table 2 were related to the motivation to purchase INA shares, the factorscoreswere calculated and the factors were correlated with the motivation variable "If I had available funds and an opportunity to do so, I would purchase as many shares of the INA company at the discount price as I could." It was found that the first factor (F1) correlated $0.26(\mathrm{p}<0.01)$, the second factor ( $F 2)$ correlated 0.45 $(p<0.01)$, and the third factor correlated $-0.19(p<0.05)$ with the motivation to purchase INA shares. Itcan be concluded that the factor political aspects of the introduction process of INA and the privatization environment in Croatia (F2) was in highest correlation with the motivation to purchase INA shares.

\begin{tabular}{|c|c|c|c|}
\hline \multirow{2}{*}{$\begin{array}{l}\text { PERCEPTIONS OF THE ATTRIBUTES OF } \\
\text { INA AND OF THE ASPECTS OF THE INA } \\
\text { INTRODUCTION PROCESS }\end{array}$} & \multicolumn{3}{|c|}{ FACTORS ${ }^{*}$} \\
\hline & F1 & $\mathrm{F} 2$ & F3 \\
\hline $\begin{array}{l}\text { I think that I can always rely on the quality } \\
\text { of INA products. }\end{array}$ & .70 & & \\
\hline I consider INA to be a well-organized firm. & .67 & & -.31 \\
\hline $\begin{array}{l}\text { I believe that the relationship of INA and its } \\
\text { customers is especially good. }\end{array}$ & .64 & & \\
\hline $\begin{array}{l}\text { I think that INA is good at combining } \\
\text { exploration directed at discovering new } \\
\text { oil and gas deposits with the activities of } \\
\text { production, distribution and sales. }\end{array}$ & .61 & .34 & \\
\hline $\begin{array}{l}\text { I have always considered INA to be a very } \\
\text { profitable firm. }\end{array}$ & .61 & & \\
\hline $\begin{array}{l}\text { I expect that the price of INA shares will } \\
\text { increase considerably in the next 2-3 } \\
\text { years. }\end{array}$ & & .63 & \\
\hline $\begin{array}{l}\text { I have confidence that the activity of selling } \\
\text { INA shares conducted by the government } \\
\text { of Croatia is sincerely motivated and } \\
\text { transparent }\end{array}$ & & .61 & \\
\hline $\begin{array}{l}\text { It is my assessment that Croatia is an } \\
\text { unstable country in which the long- } \\
\text { term stability of a company like INA is } \\
\text { questionable. }\end{array}$ & & -.55 & .34 \\
\hline $\begin{array}{l}\text { I assume that the introduction to the } \\
\text { capital market of the shares of INA is } \\
\text { politically motivated with the goal that } \\
\text { people who become shareholders of this } \\
\text { company will in the end be satisfied with } \\
\text { their purchase of INA shares. }\end{array}$ & & .53 & \\
\hline $\begin{array}{l}\text { I think that the introduction to the capital } \\
\text { market of INA shares is directed toward } \\
\text { improving the image of privatization that } \\
\text { was formerly conducted in Croatia. }\end{array}$ & & .53 & \\
\hline $\begin{array}{l}\text { Inotice that the market share of INA is } \\
\text { decreasing in Croatia and in the wider } \\
\text { region. }\end{array}$ & -.35 & & .60 \\
\hline $\begin{array}{l}\text { In my opinion, INA has numerous internal } \\
\text { weaknesses that have a negative impact on } \\
\text { its business. }\end{array}$ & -.47 & & .57 \\
\hline $\begin{array}{l}\text { I believe that the loss of market share has } \\
\text { had an important negative impact on the } \\
\text { business of INA. }\end{array}$ & & & .55 \\
\hline $\begin{array}{l}\text { I do not believe that those who have an } \\
\text { influence on the business of INA in the near } \\
\text { future will keep in mind the interests of } \\
\text { small investors. }\end{array}$ & & & .51 \\
\hline $\begin{array}{l}\text { I think that INA has so far been too little } \\
\text { concerned with unnecessary expenditures } \\
\text { in its business operations. }\end{array}$ & -.34 & & .48 \\
\hline
\end{tabular}

Table 2 Potential categories of the attributes of the INA company and aspects of the introduction process of INA shares that are the results of factor analysis $(\mathrm{N}=171)$

\section{Conclusion}

Numerousvariablesrelated to the perceptionsof theattributesofINA and theaspectsofintroduction tothecapital marketofINA shareswere analyzed by comelation and factor analyses. Itcan be conduded that the motivation to purchase INA shares was positively and negatively influenced bymanyvariableswhosenumberdoesnotpermitamore detailed elaboration of the findings in this paper. However, the first hypothesis $(\mathrm{H} 1)$, thatthe perceptionsamong potential small investors of various attributes of INA and different aspects of the introduction process of INA shares are related to their motivation to purchase INA shares in their introduction to the capital market, is confirmed. A factor analysis was performed to test the second hypotheses and three general factors were revealed that were related to the positive perceptionofcorporateimage(F1),political aspectsoftheintroduction process of INA and the privatization environmentin Croatia $(\mathbb{F} 2)$, and also to shareholder pessimism and the negative perception of the corporate image of INA (F3). Therefore, the second hypothesis (H2), thattheperceptionsoftheattributesofthelNA companyand different aspects of the introduction process of INA shares can be categorized into basic factors based on the motivation of potential small investors to purchase INA shares, is confirmed. It must be emphasized that because of the rather small convenience sample in this study, the findingscannotbegeneralized.

The results of this study can be used to create interestin the process of introduction to the capital market and also to assist in marketing efforts that precede an introduction process. However, it is necessary to attempt to reproduce at least some of the findings in another introduction to the capital marketofa large state-owned company. [.

\section{References}

Brau James C., Fawcett Stanley E. (2006) Initial Public Offerings: An Analysis of Theory and Practice, Journal of Finance, Vol LXI, No. 1, 399436.

Brav Alon, Gompers Paul A. (1997) Myth or Reality? The Long-Run Underperformance of Initial Public Offerings: Evidence from Venture and Nonventure Capital-Backed Companies, Journal of Finance, Vol LII, No.5, 1791-1821.

Chemmanur Thomas J. (1993) The pricing of Initial Public Offerings: A Dynamic Model with Information Production, Journal of Finance, Vol XLVIII,No. 1,285-304.

Cliff Michael T., Denis David J. (2004) Do Initial Public Offering Firms Purchase Analyst Coverage with Underpricing?, Journal of Finance, Vol LIX,No.6,2871-2901.

Cornelli Francesca, Goldreich David, Ljungqvist Alexander (2006) Investor Sentiment and Pre-IPO Markets, Journal of Finance, Vol LXI,No. 3,1187-1216.

Das Somnath, Guo Re-jin, Zhang Huai (2006) Analysts' Selective Coverage and Subsequent Performance of Newly Public Firms, Journal of Finance, Vol LXI,No.3, 1159-1185.

Dewenter Kathryn L., Malatesta Paul H.(1997) Public Offerings of StateOwned And Privately-Owned Enterprises:An International Comparison, Journal of Finance, Vol LII,No.4, 1659-1679. 
Druzic Ivo, Gel Tomislav (2006) Swot Analysis \& Privatisation In Croatia, Ekonomskianali168,http://www.doiserbia.nbs.bg.ac.yu/img/doi/00133264/2006/0013-32640668121D.pdf,accessed 10 September 2007.

Gerbich Marcus, Levis Mario, Venmore-Rowland, Piers (1995) Property initial public offerings: regulations, costs and price reactions Journal of Property Finance, Vol.6 No. 1,38-54.

Goergen Marc, Khurshed Arif, Mudambi Ram (2006) The Strategy of Going Public: How UK Firms Choose Their Listing Contracts Journal of Business Finance \& Accounting, 33(1) \& (2), 79-101.

Goergen Marc, Renneboog Luc (2007) Does ownership matter? A study of German and UK IPOs, Managerial Finance Vol. 33 No. 6, 368387.

Gomes Armando (2000) Going Public without Governance:Managerial Reputation Effects, Journal of Finance, Vol LV,No.2,615-646.

Grinblatt Mark, Hwang Chuan Yang (1989) Signalling and the Pricing of New Issues, Journal of Finance, Vol. XLIV,No.2,393-420.

Gupta Nandini (2005) Partial Privatization and Firm Performance, Journal of Finance, Vol LX,No.2,987-1014.

HANFA (2006) Annual Report [Online], Croatian Financial Services Supervisory Agency, Zagreb, Croatia, http://www.hanfa.hr/uploads/ AR_2006_final.pdf,accessed 10 September 2007.

Hill Paula (2006) Ownership Structure and IPO Underpricing, Journal of Business Finance \& Accounting, 33(1) \& (2), 102-126.

Howton Shelly W. (2006) Effect of Governance Characteristics on the State of the Firm after an Initial Public Offering, The Financial Review 41, 419-433.

Jain Bharat A., Kini Omesh (1999) The Life Cycle of Initial Public Offering Firms, Journal of Business Finance \& Accounting, 26(9) \& (10), 12811307.

Jenkinson Tim,Jones Howard (2007) IPO pricing and allocation:a survey of the views of institutional investors, American Finance Association Meetings (AFA), Social Science Research Network, http://papers.ssrn. com/sol3/papers.cfm?abstract_id=891396, accessed: 10 September 2007.

Kim Jeong-Bon, Krinsky Itzhak, Lee Jason (1993) Motives for going public and underpricing. New findings from Korea, Journal of Business Finance \& Accounting,20(2), 195-211.

Klačmer Čalopa Marina, Bubaš Goran, Vuković Ksenija (2007), The 6th International Symposium, Economy \& Business 2007, Economic Development and Growth, Scientific articles, Bourgas, Bulgaria, September 10-142007.

Lester Richard H.S., Certo Trevis, Dalton Catherine M.,Dalton Dan R., and Cannella,Jr.Albert A. (2006) Initial Public Offering InvestorValuations:An Examination of Top Management Team Prestige and Environmental Uncertainty, Journal of Small Business Management 2006 44(1), 1-26.

Lewellen Katharina (2006) Risk, Reputation, and IPO Price Support, Journal of finance, Vol LXI,No.2,613-653.

Logue Dennis E., Rogaiski Richard J., Seward James K., Foster-Johnson Lynn (2002) What Is Special about the Roles of Underwriter Reputation and Market Activities in Initial Public Offerings? Journal uf Business, vol. 75.no.2,213-243.

Mauer David C., Senbet Lemma W. (1992) The effect of the secondary market on the pricing oh initial public offerings: theory and evidence, Jurnal of financial and quantitative analysis, Vol 27,No. 1,55-79.

Megginson William L., Netter Jeffry M. (2001), Froma state to market: A survey of empirical studies of privatization, Journal of Econimic Literature, Vol XXXIX,321-389.

Megginson William L., Nash Robert C., Van Randenborgh Matthias (1994) The Financial and Operating Performance of Newly Privatized Firms: An International Empirical Analysis, Journal of finance, Vol XLIX, No.2,403-452.

Menon Krishnagopal, Williams David D. (1991) Auditor Credibility and Initial Public Offerings, The Accounting Review,Vol.66,No.2,313-332.

Pagano Marco, Panetta Fabio,Zingales Luigi (1998) Why do Companies Go Public? An Empirical Analysis, Journal of Finance, Vol LIII, No 1,2764.

Pollock Timothy G., Rindova Violina P.(2003) Media Legitimation Effects In The Market For Initial Public Offerings, Academy of Management Journal,Vol.46, No.5,631-642.

Rajan Raghuram,Servaes Henri (1997) AnalystFollowing of Initial Public Offerings, Journal of finance, Vol.LII,No.2,507-529.

Ritter Jay R. (2003) Differences between European and American IPO Markets, European Financial Management, Vol.9,No.4,421-434.

Schneider Friedrich (2003) Privatisation in OECD Countries:Theoretical Reasons and Results Obtained, http://www.economics.unilinz.ac.at/ schneider/PrivatizationOECDcorr.pdf, accessed:10.09.2007.

Stehle Richard, Ehrhard Olaf,Przyborowsky Rene (2000) Long-run stock performance of German initial public offerings and seasoned equity issues, European Financial Management,Vol 6,No.2,173-196.

Subrahmanyam Avanidhar, Titman Sheridan (1999) The going public decision and the development of financial markets, Journal of Finance, Vol LIV,No.3, 1045-1082.

Sun Qian, Tong Wilson H. S., Tong Jing (2002) How Does Government Ownership Affect Firm Performance? Evidence from China's Privatization Experience, Journal of Business Finance \& Accounting, 29(1) \& (2), 1-27.

Taylor D.Wayne,Warrack Allan A. (1998) Privatization of state enterprise: policy drivers and lessons learned International Journal of Public Sector Management, Vol. 11 No.7,524-535.

Tinic, Seha M. (1998) Anatomy of Initial Public Offerings of Common Stock, Journal of finance, Vol XLIII,No.4,789-822.

Wang Xiaozu, Xu Lixin Colin, Zhu Tian (2004) State-owned enterprises going public, The case of China, Economics of Transition Vol 12 (3), 467-487.

Law on the Privatization of INA Petroleum Industry [in Croatian] (2002) Narodne novine [Official Gazette], 32/02, Retrieved 26 March 2007, URL:http://www.vlada.hr/ina-privatizacija//materijali.html,accessed 10 September 2007. 